\title{
Érica Sarmet
}

Universidade Federal Fluminense, Niterói, RJ, Brasil

\author{
Marina Tedesco
}

Universidade Federal Fluminense, Niterói, RJ, Brasil

\section{Feminist Initiatives and Actions in Contemporary Brazilian Audiovisual}

\begin{abstract}
It is possible to claim that in the last two years the word "feminism" has acquired a new weight, conquering a significant space in social networks, the media and in the streets. Audiovisual was one of the areas that accompanied this recent rise of feminism, which materialized through a series of initiatives focused on claiming rights and discussing sexism in the labour market. In this article, we intend to present and reflect on eight initiatives that we consider emblematic of this contemporary intersection between feminism and cinema: Woman in Cinema, Women in Audiovisual Brazil, Black Women in Brazilian Audiovisual, Cabíria Screenwriting Award, Eparrêi Filmes, Academy of the Muses, Cineclube Delas and FINCAR - International Film Festival of Women Filmmakers.

Keywords: women, feminism; cinema; contemporary Brazilian audiovisual
\end{abstract}

It is possible to claim that in the last two years the word "feminism" has acquired a new weight, conquering a significant space in social networks, the media and in the streets. According to the study elaborated by the collective group "Think Olga" and by "Agência Ideal" (2015), from January 2014 to October 2015 the number of searches on Google for the word "feminism" increased $354,4 \%$ in Brazil only. This is a leap from 8,100 to more than 90 thousand searches. Since then, we have seen the websites, blogs, pages and groups dedicated to the theme on social networks multiply. The internet became the main place to exchange information, theories, news and opinions related to the feminist agenda, and Facebook consolidated itself as the prime tool for this, especially in forming support groups among women.

\section{(c) (7)}

Esta obra está sob licença Creative Commons. 
At the same time feeding and being fed by what happens in the networks, there is an increase in the resistance of women to the advance of conservatism in various spheres of society, and especially in politics, which threatened to withdraw hard-won rights. A series of heterogeneous, regionally decentralized protests with no single leadership, mainly against the Statute of the Unborn Child, but also having sexism, various forms of violence against women, the obstacles placed by the Regional Medical Councils to the presence of doulas in hospitals, among other causes as targets, became widely known as Women's Spring.

Audiovisual was one of the areas that followed this recent rise of feminism, which materialized itself through a series of initiatives focused on claiming rights and discussing sexism in the labour market (and how it often appears combined with discrimination stemming from race, sexual orientation, and gender identity). Thus, independent initiatives and actions have emerged with great force throughout Brazil, leading to the creation of collectives, groups, platforms, seminars, film clubs, shows and festivals dedicated to the leading role of women.

According to the Annual Report of Production of Feature Films of the Brazilian Cinema and Audiovisual Observatory of ANCINE - OCA, of the 114 feature films released in 2014, 99 $(86,8 \%)$ were directed by men, $11(9,6 \%)$ by women and $4(3,5 \%)$ had a mixed direction. Of these, 82 works that obtained authorization to apply to indirect federal funding, and in which gender proportions practically did not change, were 71 feature films $(86,6 \%)$ with male direction, $8(9,8 \%)$ with female direction and $3(3,7 \%)$ with mixed direction. When we turn to the finished films, the numbers are equally disparate. Of the 186 feature films completed in $2014,156(83.9 \%)$ were directed by men, $28(15.1 \%)$ by women and $2(1.1 \%)$ had mixed direction. In the 76 completed projects that obtained authorization to obtain indirect federal funding , there was an even greater gender inequality: 65 feature films were male-directed $(85.5 \%), 10(13.2 \%)$ female-directed direction and 1 (1.3\%) had mixed direction.

Until a few years ago, little was discussed about gender inequality in the Brazilian audiovisual market, even if our cinema has already met with feminism in previous decades by means of filmmakers such as Helena Solberg and Tereza Trautman, in the 1960s and 1970s, and in the 1980s via the Collective of Women in Cinema and Video of Rio de Janeiro, among others. In order to counter the discrepancies presented in the above data, women in cinema began to organize themselves to reverse such a situation, especially from 2015 on.

In 2016, we saw feminism gain strength in the cinema and expand even more. Film clubs popped up all over the country, such as the Academia das Musas (RS), QuaseCatálogo', CineclubeDelas e FacçãoFeminista (RJ), Aranha (BH) and A Hora e a Voz da Mulher no Cinema (SC); collective groups were formed, such as the DAFB - Collective of Brazilian Directors of Photography (national), We Are More than $30^{2}$ (SP) and Women in Audiovisual (PE); and platforms were created in order to give visibility to the work of women and promote contact among them, like the group Black Women in the Brazilian Audiovisual.

In this article, we intend to present and reflect on eight initiatives that we consider emblematic of this contemporary intersection between feminism and cinema: the website Women in Cinema, the Facebook group of the Women of Audiovisual Brazil, the Black Women in the Brazilian Audiovisual platform, the Cabíria Screenwriting Award, the production company Eparrêi Filmes, the Cineclube Academia das Musas, the Cineclube Delas and the

${ }^{1}$ About the Quase Catálogo and feminism in the film movement, see SARMET \& TEDESCO, 2016.

${ }^{2}$ Somos Mais Que 30 (We Are More than 30) (https://www.facebook.com/somosmaisque30/) is a collective group composed by women that work with audiovisual. It was created after a case that happened in Rio de Janeiro in the first semester of 2016 , when a girl was raped by at least 30 men, who posted online the videos they made during the crime. The objective of the group, according to member Gabriela Fernandes, in an interview held on December 5,2016 , is to combat violence against women. 
FINCAR - International Film Festival of Filmmakers. This selection was made after a wide collaborative mapping and we have tried to contemplate performance and regional diversity, besides prioritizing those that, although recent, have demonstrated continuity in their actions.

\section{Woman in Cinema}

Since July 2015, journalist Luísa Pécora dedicates herself to the "Mulher no Cinema" (Woman in Cinema), a website daily updated with news, interviews, videos, reviews and research on professional women in the Brazilian and International Film Industry. After watching The Hurt Locker (2009), by Kathryn Bigelow, and observing the discussions that following the victory of the first woman ever to win the Best Director's Oscar, Pécora realized that promoting gender equality on the screens would be a way to promote gender equality in general. In 2013 , working at the online portal iG, the journalist wrote a series of reports on the topic of woman in the cinema, which continued for approximately two years. The good repercussion among readers made her realize that there were more people interested in the subject besides her, but the debates in Brazil were much less advanced than abroad. There was no vehicle that produced content in Portuguese on this issue, making it more accessible to all and bringing together in the same place the information related to the agenda. Thus, in June 2015, Pécora created the Woman in Cinema, in order to share the knowledge that she acquired during the years of research dedicated to the leadership of women in the cinematographic milieu.

According to its creator $^{3}$, the website has the following main objectives: 1) to raise public awareness about gender inequality in the audiovisual sector; 2) to give voice to women who make movies; and 3) to put the public in contact with filmmakers, and vice versa. Among the main activities she developed are interviews with professionals and dissemination of films directed and / or starred by women. The journalist points out that the Woman in Cinema makes a general coverage of vehicles of culture, but always in search of the angle that relates to women. Like most vehicles, the Woman in Cinema publishes a weekly list of films showing in theatres - however, the focus is only on those written, directed and / or starred by women.

Like many other media portals, Woman in Cinema suggests movies to be watched on Netflix, but keeping the focus on films directed by women. Likewise, when lists of nominees for cinematographic awards come out, the coverage of the site specifically addresses the women indicated: it points out the proportion of women compared to men, presents previous work done by these women and investigates historical data, such as the number of women already indicated in each category of a specific award. The differential of the Woman in Cinema from other similar vehicles is, therefore, the diffusion of cultural events dealing with female protagonism.

According to Pécora, the Woman in Cinema tries to gather as much content as possible (news, previews, data, studies, reports that have appeared in the foreign press) so that the reader follows the main discussions and films without having to "hunt" for information in many different sources - especially when these sources depend on knowledge of the English language. As significant results, the journalist points the more than 19,200 likes in about a year and a half of the existence of the Facebook page, an impressive number taking into account that it is an independent initiative, not linked to any vehicle or portal and that does not receive sponsorship. In 2017 , the journalist plans to become more visible offline, promoting debates, shows and workshops.

${ }^{3}$ The informations and quotes credited to Luísa Pécora in this paper are the result of an interview made by email on December 9, 2016. 
We can affirm that the Woman in Cinema is an emblematic example of how the last two years represented an unprecedented advance in the debate about gender inequality in Brazilian cinema. Pécora says that when she did her first report on the subject in 2013 , she had difficulty obtaining sources for interviews, besides having to count the releases of Brazilian directors on her own, since ANCINE still did not estimate or make such data available. Today, many filmmakers speak openly about the issue of women's protagonism and of sexism in the audiovisual sector, in addition to having access to more numbers, studies and research, even though these are not yet consolidated initiatives. On the other hand, she considers it too early to know if this movement necessarily means a real change.

Statistics have not yet shown significant improvement in the female presence in front of or behind the cameras, and it will take a few years for us to know the practical effect of this greater engagement. So I would say that it is important to celebrate the initiatives that have appeared, but with the awareness that there is a lot of work ahead. Women in the movies is the subject of the moment, but it has to remain a subject. Until it ceases being a subject.

\section{Women in Brazilian Audiovisual}

With more than 9 thousand professionals registered at the time of this writing, the Women of Audiovisual Brazil is the largest group on Facebook of women related to the area. The group began in September 2015, after the first meeting of women from the area at Spcine $^{4}$. According to Malu Andrade ${ }^{5}$, coordinator of Innovation, Creativity and Access of Spcine and administrator of the group, at first the space would be only for those present at the meeting, in order to exchange ideas after the meeting. With the high interest from other professionals, however, the group grew beyond its walls. By the end of the week it was open for membership, there were more than 500 women.

Andrade emphasizes that, even though she is the only administrator, the group has a horizontal and collaborative aspect, and its functioning is due exclusively to the autonomous participation of women. It is a network of exchanges, debates and networking, which works by strengthening the hiring of more women, the articulation between professionals in the field and the establishment of businesses. Among the concrete results obtained are the emergence of regional groups, which have strengthened the local networks of states where public policies are often lacking, and projects that have materialized only due to the articulation provided by the online group.

After the creation of the group there were at least two meetings: a general one, in November 2015, dedicated to the discussion of the development of a quantitative research on women in Brazilian audiovisual, besides the discussions of important guidelines for feminism in the audiovisual; and another on November 17, 2016, during the Spcine Encounter. In the latter, a one-year review was made of the group Women in Audiovisual Brazil since the first meeting promoted by Spcine with representatives of the sector. The review evaluated the achievements in terms of public policy and what would be the goals for the next four years.

Andrade says,

the most important thing now is the organization and updating of data related to the different areas of cinema, to allow for the elaboration of good public policies from the recognition of the demands of women in the sector.

${ }^{4}$ Film and audiovisual company of São Paulo, linked to the Municipal Secretary of Culture.

${ }^{5}$ The information and quotes credited to Malu Andrade in this article are the result of an interview conducted by email on December 8, 2016. 
This is one of the actions that have already started from the group. Since November last year, a survey has been made on women in the Brazilian audiovisual sector. Organized by the researcher and filmmaker Amanda Lopes, the research brings very interesting data. Its last part, dated June 30,2016 , had the answers of 1,130 people and provided the following information:

- $\quad 97 \%$ consider themselves women (we imagine that the other $3 \%$ identify themselves as trans men or non-binary people);

- $\quad 66 \%$ of women consider themselves white; $22.2 \%$ brown and black; $8.1 \%$ answered "none"; $2.65 \%$ yellow; and $1.15 \%$ indigenous;

- $\quad 66.1 \%$ say they are heterosexual; $18.2 \%$ bisexual, $8.1 \%$ lesbian, $6.10 \%$ preferred not to respond; $1.15 \%$ were said to be pansexual and $0.26 \%$, asexual;

- $13.6 \%$ are between 20 and 24 years old; $27.2 \%$ are between 25 and 29 years; $24.7 \%$ are between 30 and 34 years; $14.8 \%$ from 35 to 39 years; $8.2 \%$ are between 40 and 44 years; $5.13 \%$ are between 45 and 69 years; $1.15 \%$ are between 15 and 19 years old;

- $48.3 \%$ completed graduation; $14.8 \%$ have undergraduate courses in progress, $15 \%$ have completed graduate studies; $5 \%$ have graduate studies in progress; $13 \%$ other schooling;

- $\quad 54.2 \%$ said they survived on audiovisual revenues, while $45.8 \%$ said they did not;

- $\quad 44.7 \%$ do not have a monthly salary; $21.9 \%$ receive from $\mathrm{R} \$ 3,1502.1$ to $\mathrm{R} \$$ $7,880.00 ; 15 \%$ receive from $\mathrm{R} \$ 1,576.01$ to $\mathrm{R} \$ 3,152.00 ; 8.9 \%$ receive from $\mathrm{R} \$$ $7,880.01$ to $R \$ 15,760.00$ and $0.97 \%$ receive more than $R \$ 15,760.00$;

- $\quad 77.6 \%$ do not have children, $22.4 \%$ do.

Although they are partial data of a research in progress, such information already allows us to raise some questions. Women in the audiovisual sector in Brazil have a high level of schooling and more than $80 \%$ are of productive age. However, it is alarming that $45.8 \%$ do not survive exclusively on the income from their audiovisual work. This information solidifies when analysed jointly with another, the salary range: the majority, $44.7 \%$, do not have a monthly salary, that is, they work as freelancers, with variable income.

Brazilian cinema is still proves to be a space dominated by white and heterosexual women: they represent, respectively, $66 \%$ and $66.1 \%$ of professionals. The fact that $77.6 \%$ do not have children can also be useful to investigate the conditions of motherhood in the audiovisual field. The instability of the area, the lack of regulation of the professions, the lack of childcare facilities and long working hours may be some of the reasons why this large number of women chooses not to have children, but this debate is still far from the reality of companies and professionals.

When questioned about formalizing the Facebook group as a national association, Andrade replied that it is difficult to do so; however, she considers that it would be very interesting for the women participating in and affiliated to associations to form boards and run for board membership in their associations, reinforcing the voice of women with public organizations.

\section{Black Women in Brazilian Audiovisual}

The platform Black Women in Brazilian Audiovisual consists mainly of an online database where, on one hand, indigenous and black women who work with audiovisual in the country can display their curricula and portfolios, and, on the other hand, people interested in hiring professionals may search for the profiles they are interested in. 
Its creator was filmmaker Carol Rodrigues, from São Paulo. Graduated in Social Sciences with complementary training in Cinema, in 2016 she participated in an Introduction to Programming course promoted by "PrograMaria", which aims to encourage more girls and women to enter the field of programming.

The aim of the course was to enable women to take their first steps in Front-End Programming (HTML, CSS and JavaScript). Since we needed to deliver a site as the final course project, it seemed a good idea to use my knowledge for an end that was not just individual, like a portfolio. Audiovisual is a very racist and sexist area and for some time we have been discussing ways to give visibility to ourselves, black professionals, and to our projects. So, I thought it was a great idea to try to develop something along these lines, to create a platform that could be useful as a visibility tool for black audiovisual professionals. ${ }^{6}$

The motivations for the construction of the platform are very clear in Rodrigues' speech, but some data help to illustrate the real dimension of the underrepresentation of black women in Brazilian audiovisual. According to research developed by the Group of Multidisciplinary Affirmative Action Studies (GEMAA) of the State University of Rio de Janeiro, between 2002 and $2012^{8}$, women directed only $13.7 \%$ of the highest grossing films, and black and brown people, 2\% (Verônica TOSTE \& Marcia Rangel CANDIDO, [s/d.]), being that no black filmmaker was found in the 218 productions analysed.

It must be recognized that from 2012 until now some significant changes have taken place. At least for those who accompany the audiovisual beyond theatres (i.e., shows, festivals, film clubs, etc.), it is impossible not to meet the directors Larissa Fulana de Tal, Yasmin Thayná, Sabrina Fidalgo, Viviane Ferreira, among others. And filmmaker Adélia Sampaio, the first black woman to make a feature film in Brazil, has finally received the recognition she deserves through various honours.

However, black women's conditions of entry and permanence in the area are still far short of what would be fair, and there is neither sufficient public policy nor commitment from audiovisual professionals as a whole to bring about significant changes in the short term in that framework. On the contrary, the public funding "CurtaAfirmativo", known for being the first affirmative action with a racial profile in the country's audiovisual, for example, was challenged in court and, after an edition, discontinued?.

Thus, a platform like Black Women in the Brazilian Audiovisual becomes urgent. With 78 women registered by the time this article was written, it offers the following search filters: alphabetical order, State (you can select more than one at the same time) and function there are 38 functions available, which include activities outside the process of realization, such as teaching and criticism. Rodrigues says there is still room for improvement. Until then those interested send their information by filling out a form and people have to transfer the data to the platform. The idea is to make the process more dynamic, with women being able to access and edit their profiles more quickly.

${ }^{6}$ The information and quotes credited to Carol Rodrigues in this article are the result of an interview conducted by email on December 12, 2016.

${ }^{7}$ We will address only the underrepresentation of black women because we have no data to make considerations about indigenous women. However, it is important to emphasize that the absence of these in the Brazilian audiovisual is blatant and brutal.

${ }^{8}$ The National Cinema Agency - ANCINE made available in 2016 a survey about the directors in the Brazilian audiovisual sector. However, since the race variable is outside the scope of the investigation, we prefer to work with the GEMAA material.

${ }^{9}$ The funding Carmen Santos Cinema for Women, another affirmative action launched in the same period of the "CurtaAfirmativo", was not so contested. However, its fate was also discontinuity. 
In general, I believe that, in addition to our own dedication, the places we occupy were only made possible by the sacrifice and effort of others. Nothing will be given to us. It's up to us to organize ourselves, create our own tools, and open up more space and more achievements with our own hands. A recent example is the initiative to create the APAN, Black Audiovisual Professionals Association in São Paulo.

In fact, it is possible that with the recent creation of Apan and its participation in institutional spaces, such as SPCine's Advisory Board, we will see improvements in a while. But for black women, who cannot and do not want to wait, Black Women in the Brazilian Audiovisual can be an important space of opportunity and visibility.

\section{Cabíria - Screenwriting Award}

Cabíria is a screenwriting award for stories with female protagonists. Its objective is to improve in quality and quantity the presence of women in front of and behind the cameras. The project officially began in August 2015, when Marília Nogueira, from Ipê Rosa Productions, created the Facebook page to publicize the prize and the collective financing campaign. Without the Internet crowd funding the project would not have achieved its main objective, which was to provide money awards to the winning screenwriters. At the end, it was possible to reach and surpass the goal of the collective financing, collecting about $R \$ 20,000.00$. In addition to receiving money, which is known to be insufficient to make most films viable, winning the contest contributes to the visibility of the screenplays and to their chances of obtaining funding and reaching theatres. In an interview ${ }^{10}$, Nogueira says that several issues mobilized her to create the Cabíria:

In 2008 I participated in an artistic residency for young filmmakers from Latin America, the Taller de Desarrollo de Proyectos Cinematograficos da Fundación Typa, in Argentina. It was an experience that struck me a lot and I started thinking about doing something similar in Brazil one day. The years passed, the project seemed too big and I forgot about this story for a while. At the same time, I became aware of the impact of gender inequality on various aspects of my life. I directed two short films and wrote many scripts and short stories and, with rare exceptions, my protagonists are male. My impulse is to write male characters or tell stories from a male point of view. It makes no sense. I am a woman. It would be much simpler and logical that my impulse was the opposite, to write from a feminine point of view. Write about and for women. But no. There were so many books, movies, cartoons and comics from my childhood and adolescence with male protagonists that my brain must have grasped this data as being natural. I started reading a lot and talking with other women about these concerns. The idea of creating an artistic residency came back and, I do not remember exactly how, became the project of a prize for stories with female protagonists.

Thus, the scriptwriter and assistant director was launched in the work of elaborating the Cabíria. She had help from designers Rita Faria and Luiz Arbex, creators of visual identity, who contributed with criticism and suggestions throughout the process of creating the first edition, and other important partnerships such as WIFT Brazil, Women in Film and Television Brazil and female screenwriters' volunteers.

In the first stage of the selection, 12 professionals voluntarily read 158 received scripts. There were 165 entries, 158 valid ones, among which 102 scripts of female authorship and 56 of male authorship or co-authorship. The director and scriptwriter Thais Fujinaga received R\$ $10,000.00$ for the first place. Guilherme Macedo came in second place and Cecilia Engels in third. They received the Eleonora Loner and Marton Olympio honourable mentions.

${ }^{10}$ The information and quotes credited to MaríliaNogueira in this article are the result of an interview conducted by email on December 9, 2016. 
Despite the success of the awards and the visibility that the five finalist writers won after participating in the selection, funding for the second edition is still an open question, according to Nogueira. The screenwriter has plans to open a legal entity for the project in order to raise funds through incentive laws and miscellaneous funds. Collective financing via the Internet is still a possibility, but it is a type of funding that demands a lot of time from those involved, as it requires a great work of dissemination and mobilization in the networks. There is also the idea of creating a script platform based on the American site "The Black List", reversing the platform's profit to the script award.

\section{Eparrêi Filmes}

Sensitization to the issues of feminism in recent years has led to an increase in the volume of audiovisual production by women, especially in the areas of short films and collective works in various formats and for various windows, but also in a change in how and why to produce. And, in this sense, the trajectory of Eparrêi Filmes is quite emblematic.

With a name that honours the orixá Yansã, "orixá warrior, lady of the winds and of lightening, that tolerates no type of prejudice and is the protector of independent women"11, it is headquartered in the State of Amazonas, where its activities began in early 2015. Motivated by the perception that cinema is still basically made by white men from the Rio de JaneiroSão Paulo axis, the partners Elen Linth and Riane Nascimento decided to focus on the potential of the North Region to develop products that had more affinity with their identities in terms of ethnic, racial, class, and sexual orientation.

Eparrêi is directed and coordinated by lesbian women, of popular/ quilombola origins, that seek to envision audiovisual through the perspective of black, poor, lesbian woman, without reproducing the same stereotypes that have represented women throughout the history of cinema.

The objectives that guided the creation of the production company are very evident when we focus on the contents already produced and those in development. Funded by the Sectorial Audiovisual Fund (FSA / ANCINE) through the North Region TV Public Funding, the "Territories" documentary series (to be released in 2017), composed of 5 episodes, focuses on home address discrimination and urban mobility. These are undoubtedly issues covered in other works. However, in Territories, Manaus reaches the public from the point of view of 5 women: Mikaela, a resident of a stigmatized community in the city; Maria, a young transvestite who studies Pedagogy; Andria, who lives in an occupation and participates in the struggle for housing; Cida, an indigenous rapper; and Sara, a poet who sells fanzines in the streets.

It is important to note that even though the series focuses on the above-mentioned crucial issues for the characters such as being a transvestite, other issues such as affectivity in the city and autonomous motherhood are not ignored by the director Elen Linth, who seeks to establish, between them and others, dialogues which are structural, but impact the lives of individuals.

In 2017, Eparrêi will film "Crossings", a feature documentary also financed by FSA/ ANCINE, about the Haitian immigration in Amazonas. Here, once more, a peripheral woman will be guiding the narrative. Nadie, a black Haitian, mother of two children, who entered clandestinely in Brazil and had to wait five years for her refugee status to be recognized, will return to her country crossing the borders Brazil-Peru-Colombia-Dominican Republic-PanamaHaiti.

\footnotetext{
${ }^{11}$ The information and quotes credited to Elen Linth in this article are the result of an interview conducted by email on December 10, 2016.
} 
A study by researchers Denise Cogo and Terezinha Silva demonstrates the importance of the emergence of new views on topics in vogue in the mainstream media in our society.

If, in early 2013, some narratives attribute to the "outbreak of immigration" of Haitians, "who entered illegally in Brazil", the responsibility for creating "a serious social problem in Acre", in early 2014, new reports evoke again the Haitian immigration associated with "problem", "massive arrival", "invasion", "uncontrolled by the authorities" and "illegality by the immigrants", etc. In the context of a new entrance movement of Haitians - about 70 a day in Brasileia, Acre -, narratives evoke the situation of "public calamity" and the need for "border closure". At the same time, they emphasize the "lack of infrastructure of the shelter occupied by immigrants and the scarcity of food".

Although obviously a documentary with such theme and produced by a small producer has a much smaller scope - according to ANCINE, the biggest box office of the genre in the last five years were: 2011 -Bahêa My Life (MárcioCavalcante), 74,857 people; 2012 - Raul - o Início, o Fim e o Meio (Walter Carvalho \& Evaldo Mocarzel), 170,471 people; 2013 Elena (Petra Costa), 58,614 people; 2014 -Tarja Branca (Cacau Rhoden), 14,892 people; and 2015 - Cássia Eller (Paulo Henrique Fontenelle Migdal), 75, 133 people -, we consider it fundamental that other narratives and representations begin to be constructed.

In terms of production structure, Linth and Nascimento participate in a trend which, although not reaching the majority of the audiovisual scene, has been increasing in several countries: the political option of privileging women in the formation of the teams. Thus, they have established that in the Eparrêi films and series $75 \%$ of the team heads must be women. However, there is yet another guideline: that $75 \%$ of the people in the teams be black. Thus, one of the main slogans of the producer is guaranteed: "for us, black women will always be in charge".

We believe that we are agitating the Amazonian scenario with the proposition of themes that are little discussed in the region, as well as having discussed the role and place of women in Brazilian cinema and production. We are also promoting the decentralization of film production as well as consolidating the North as a region that thinks and produces content for the cinema and TV from a woman's perspective.

\section{Academy of Muses}

In the field of initiatives aimed at the exhibition of women's films, 2016 will be remembered as an extremely fruitful year. Already on January 9, the Academy of the Muses ${ }^{12}$, a new group of studies dedicated to the research, debate and diffusion of cinematographic works directed by women, is established in the Multimedia Room of the Cinemateca Capitólio, in Porto Alegre.

The initiative begins to be conceived in 2015 , when some of its members (it is a mixed space), then linked to the Aurora study group, examined a doctoral thesis (Luiz Carlos Golçalves de OLIVEIRA JÚNIOR, 2015) where there was a chapter dedicated to the feminine point of view in Vertigo (1958) and another on female orgasm in the movies. After the reading, they decided to enter the field of gender, but with a significant shift: instead of women in front of the cameras, the ones that determine what and how the cameras should film.

After outlining what they would do, they started looking for a name, which came with the exhibition of Academia das Musas (2015). At first it is strange that a project with the objective of privileging female directors adopts the title of a feature film made by a male filmmaker. However, according to member Juliana Costa:

${ }^{12}$ The study group Academy of Muses, like its predecessor Aurora, is not tied to any institution. It brings together people from different universities, but also from the cinematographic milieu and from society in general. 
Academy of Muses is the appropriation of two ideas that we somehow question in the practices of our study group: the "academy" as the only legitimate locus of knowledge production and research, and "muses" as female entities for the cult of beauty and inspiration. Appropriating and subverting concepts we historically helped to construct seemed more interesting to us than throwing them at the stake. Taken as reflection or as a joke, it is a name that concerns us: the movie theatre is our Academy and we draw inspiration from our inspired muses. ${ }^{13}$

The next step was to make a public call on Facebook in December 2015 and early 2016 , so that more people would know the proposal, and to call a face-to-face meeting that would bring together all those interested. At the meeting, the movie Girls (2014) was shown. Among the innumerable possibilities of women's films, this one was chosen due to the fact that it had not been shown in any cinema of the city and because of the interest of one of the members, who was investigating audiovisuals with black protagonists (women and men).

As in the case of this first session, the other sessions (biweekly, held on Saturday mornings) were also marked by the lack of viewing on the large screens and the interest of one of the people in the group - since one of them is always responsible for researching the work, bringing data to contribute to the discussion.

Although there is no a priori concern to contemplate different modes and places of production, the plurality of the studied material is visible. Focusing primarily on feature films (perhaps this is the most constant feature of the curatorship, although there are exceptions), and not in the director's filmography, Academy of Muses throughout 2016 chose to watch and debate ten European films - especially French films - three American, two in co-production Europe / United States, three Latin American, three Asian, two African (one in co-production with France), one Soviet and one from Oceania. In addition, they organized special sessions in the exhibit circuit and within thematic exhibitions. In these specific cases, the main criterion for choosing was to obtain the right of exhibition.

Regarding the number of participants, after a great initial approximation the number stabilized around 12, who attend almost all the meetings, and 10, who participate in some. There are also spectators - men and women - without any involvement with the group, but who eventually go to one of the organized activities.

By combining very different profiles, it is difficult to assess the impact of the initiative on each one's life, but it is clear that it exists. There is, for example, the story of a woman from outside the audiovisual area, but who had always had an interest in cinema, who began to write about the subject and was recently in an international festival. And also the story a member of the group's father that ended up becoming more assiduous than she was and is also venturing to write. There are many other situations related to the impact.

Trying to reflect more generally, Costa states:

Thinking about the gender issue, well, I think it's fundamental! I think it's fundamental that when we think of first cinema, we think of Lumière, Méliès, but also think that Alice Guy made colourful films much earlier, experimented with very sophisticated sound, that Lois Weber ushered in the suspense genre, that people wait for the next Mia Hansen-Love movie as we expect the next one from Miguel Gomes. That the work of these women is in our conversation and in our thinking for the quality they have, because they were pioneers, risked, tried, finally created, they looked at the world ... So I think this type of group is important also for people to realize that women are already represented, once we learn how to look.

${ }^{13}$ The information and quotes credited to Juliana Costa in this article are the result of an interview conducted by email between December 5 and 7, 2016 . 


\section{Cineclube Delas}

The "Cineclube Delas" emerges as a project in May 2016, when film critics Camila Vieira and Samantha Brasil, who already had a personal project of watching more female movies, glimpsed the possibility of creating a feminist film club at "Tempo Glauber", in Rio de Janeiro.

At first the idea was not to work only with women filmmakers, taking to the screens also productions directed by men in which the protagonists were women. However, after the first session, which took place on July 14, where the short filmWomen Reply (1975) and the film She's Beautiful When She's Angry (2014) were screened, followed by a debate with writer Marcia Tiburi, teacher Susana De Castro and filmmaker Sabrina Fidalgo, they realized the enormous demand for focusing only on female filmmakers ${ }^{14}$.

According to Brasil and Vieira ${ }^{15}$, this demand relates, on the one hand, to the need to expand exhibition spaces that program audiovisual works by women directors. In the two sessions where they opened a call ("being a woman" and Special Edition: Launching of the Collective Photographic Directors of Brazil - DAFB), they received a huge number of films. In addition, even without being open call, women directors who do not find space in the festivals curators and movie theatres have contacted them.

At the same time, the importance of opportunities to discuss issues facing feminism and guiding the sessions stands out: cinema and feminism (July), "being a woman" (August), new conjugalities (September), trans visibility (November) and the body as performance of the feminine (December). Although there are people who always accompany the "Cineclube Delas", most of the audience is variable and people often come because they are interested in a specific theme that is needed to talk about. Such urgency is perceived in the interventions that are made, but also in the many embraces and emotional thanks that happen in the end of the activity.

As far as curatorship is concerned, in addition to the format of the film club, there are no pre-defined guidelines. The sessions may be motivated by a specific work already watched, by the desire to address certain issues, by the above mentioned contacts made by the filmmakers ... The major reasons we could identify highlight the short film, which is never absent, and, except from the premiere, when a French and an American production were shown, a preference for Brazilian film ${ }^{16}$.

On the debates, there is a concern to combine the presence of female directors with women from other areas. The intention is that discussions should not be confined to formal or even narrative aspects, but that they allow, with e cinema as the starting point, to begin to think about more general features of our society, if and how they oppress women, personal experiences and possibilities of transformation - let us remember that the first structural axis of the film was feminism, with female directors incorporated later.

Following the tradition of many film clubs, Delas extrapolates the dual viewing/debate and, in addition to using its Facebook page to replicate news pertinent to its proposal, also produces content. We can mention, by way of illustration, the list of 100 Best Films Directed by Women in the 21st Century (CINECLUBE DELAS, 2016), with 125 shares so far. Beyond a

\footnotetext{
${ }^{14}$ In November, two transgender directors entered the program. Since transsexual men often face prejudice and violence similar to those inflicted on women, this was not seen as a departure from the film's proposal.

${ }^{15}$ The information credited to Samantha Brasil and Camila Veira in this article is the result of a face-to-face interview, held on December 8, 2016.

${ }^{16}$ It is interesting to note that ending up exhibiting almost exclusively national films, even without having a policy previously defined in this sense, is a phenomenon that occurs in other Brazilian film clubs. In the film club

"QuaseCatálogo, almost the same happened: of the 8 sessions only one was dedicated to foreign production.
} 
definitive sentence, it is intended to be a response to the lists of best films, in which women rarely appear (in the French Télérama (TÉLÉRAMA, 2016), which irritated/inspired Vieira and Brasil, of the 100 elected only two were female filmmakers) and a provocation so that these and other works get a higher attendance.

By the end of 2016, there were 9 editions, of which 6 were regular and 3 special (DAFB's launch, at "Tempo Glauber", "Ocupa IFCS/UFRJ"17 and "Sarau do Escritório na Lapa"18), which, together, were the stage for 6 feature films and 18 short films. And in non-qualitative terms, the organizers report that all the stories they heard in the second half of the year only reinforced the need to continue with the initiative in 2017.

\section{FINCAR}

Created in 2016, FINCAR took place in July in the city of Recife (PE), produced by Orquestra Cinema Studios and Vilarejo Filmes and made possible by the Government of Pernambuco through the Funcultura Audiovisual. Focusing on women in the film direction, the festival aims to investigate creative audiovisual processes by women. As stated on its website, the

FINCAR has as motivation to foment the debate around cinema and the woman who observes and is observed. We will investigate the freedom of forms and themes in long, medium and short films. Our interest is on the achievement that is geographically decentralized. Here, internationality is understood as a bridge that respects the singularities of the works, the authors and the places of exhibition. It is a dialogue between attentive visions to the contexts of achievement. We understand the film festival as a space for exchanges between filmmakers and the public. It is a moment to think about art, authorship, gender and the social web around these issues (2016).

In partnership with the Pernambucana's Federation of Film Clubs, FINCAR also performs the FINCAR - FEPEC Film Club Circuit, which allows the films to be exhibited in other cities of the State of Pernambuco as well. The festival occupies the vacant space left by FEMINA, the largest and oldest Brazilian festival dedicated to women, which held its eleventh and last edition in 2014, due to lack of sponsorship for the following years. Unlike FEMINA, and in this sense, updating itself in relation to contemporary feminist demands, FINCAR does not accept films directed by men - unless in co-direction with a female director. The festival has its artistic direction, curatorship and production only by women, and a criterion for team selection quite in tune with the present moment, as already discussed in previous pages.

In this first edition, 30 films from 19 countries were selected, among more than 2,400 entries of short, medium and feature films worldwide. In an interview with the journalist Luísa Pécora, of the Woman in Cinema, Maria CARDOZO (2016), artistic director and curator of the festival, tells what motivated her to create it:

In 2014 I saw a Brazilian actress who I admire a lot winning a performance prize at a traditional film festival. She gave a speech alerting us to the types of female characters we see on the screen. And she also talked about the importance of her relationship with the director, for being two women, in that movie. It hit me hard. I was at the festival with a movie I had worked on, but that year I was especially in intense research on women artists in video art. It was curious to realize that I knew a lot more achievers in the visual arts than in the movies. I began to narrow my research between film and video art and began to find texts that showed the reasons for this difference.

\footnotetext{
17 Student occupation of the Institute of Philosophy and Social Sciences of the Federal University of Rio de Janeiro.

${ }^{18}$ Event that promotes the occupation of streets with various cultural activities. At the invitation of the Feminist Faction Film club, the Delas and QuaseCatálogo Film clubs curated a short film by a woman to be screened.
} 
For Cardozo, the workspace of the cinema and its hierarchy never favoured the presence of the woman as director.

In the case of video art, "amateur" cameras gave freedom of use, including for domestic spaces. That's decades ago. But there are still directors who say women are better producers because they already have the ability to take care of home and family issues. To deconstruct this space of the woman character made to be looked at by the man and to look for the things that hold the look of women filmmakers motivated me to create the festival.

The founder of FINCAR also says that it is important to discuss the importance of a festival focused on women directors, especially when faced with resistance to this idea by older filmmakers. "Festivals dedicated exclusively to women filmmakers are nothing new. If filmmaking is still mostly men, we need to affirm the achievement of the woman so that she can grow stronger and grow" (CARDOZO, 2016).

\section{Final Considerations}

Researcher Suely Gomes Costa (2009), recovering the critical debate about the concept of wave to think the feminist movements, believes that it is possible to reconcile this concept, limited in the view of certain female and male authors, with that of rhizome, sometimes pointed out as its substitute.

Both [waves and rhizome] are useful as metaphors; they are not mutually exclusive, for together they translate convergent concepts; but it is indeed necessary to distinguish between them. There are, in feminisms, multiple and simultaneous times to be known, observing that there are generations of different women and feminists, who interact in several states of consciousness and multiple identities (HALL, 1994) in circulation, at a given time. There are events to observe, hence the short run, the conjunctures, therefore; but there are also manifestations in the long run - not perceptible - forged, in submerged "structures", intertwined or not to these same events, redefined or not; they are in the history of feminisms (COSTA, 2009, p. 10).

We are not unaware that there are manifestations in the long run and submerged structures intertwined with the events, the short run and the conjunctures here discussed. However, we chose to devote ourselves to the last three because we consider that the contemporary Brazilian audiovisual lives, in terms of the engagement and organization of women around feminist themes, a unique moment in its trajectory. Faced with this, it is important to get away from the intense flow of events, where we are inserted as filmmakers and writers and photographers and club members and militants, to try to understand, even if incompletely, a phenomenon felt by many people, but about which there are almost no texts and data.

And the very path in search of that understanding has already given us some precious clues. In methodological terms, we have decided to begin with a mapping of the broadest possible range of feminist actions and initiatives taking place in the area. To do so, we activated our personal and professional networks, which often overlap, and we made a post asking for help in the Facebook group studied here Women of Audiovisual Brazil. At the same moment, members began to respond, suggesting names and marking other women who could contribute. As a result, by the end of that day we had dozens of possibilities to be investigated.

Along the way, deepening our knowledge about so many actions and initiatives, we realize that what happened to us in this post and what we experience daily in the curatorship 
and production of the "Quase Catálogo" are not isolated cases. Many women in the audiovisual sector are really engaged in changing the adverse scenario where they act or intend to act, investing part of their time in their projects or even others that can contribute to this goal.

In addition, as we pointed out in the first pages and when dealing with the 8 initiatives addressed, the Internet is usually much more than a space for the dissemination of films and activities - although it is also this space, which is very important. For some, such as the website Woman in Cinema, the Facebook group Women of Audiovisual Brazil and the platform Black Women in the Brazilian Audiovisual, for example, this is the arena itself. However, it is essential to emphasize its role as a place for information and training - not only on audiovisual but also on feminism - and in the articulation of fronts and collaborative actions, where the engagement mentioned in the above paragraph finds several ways (which, of course, are not the only ones) to take effect.

The Internet also contributes to a memory of the feminist movements that are taking place in contemporary Brazilian audiovisual. However, it is known that such a contribution is made through dispersed, disorganized information, often produced without the intention of being a record, and even less a logical, organized and fast-access set. This is the other reason why we focus on events, short times, and conjunctures. While there is a proliferation of actions and initiatives, it is necessary to begin to gather the material spread on the internet and complement it with other sources if we want to be protagonists in writing the narratives about us, women of the audiovisual, and create a scenario in which it becomes increasingly impossible to find books about cinema where women directors, producers, writers, photographers, critics, exhibitors, etc., are absent.

Although the tone of the article has been one of optimism, because regardless of any statistics we live an extraordinary moment, we also need to look at some data regarding the period. Based on data provided by the Brazilian Cinema and Audiovisual Observatory OCA, from ANCINE, we elaborated the chart 1:

Graphic 1: Brazilian films released X Films directed by women released

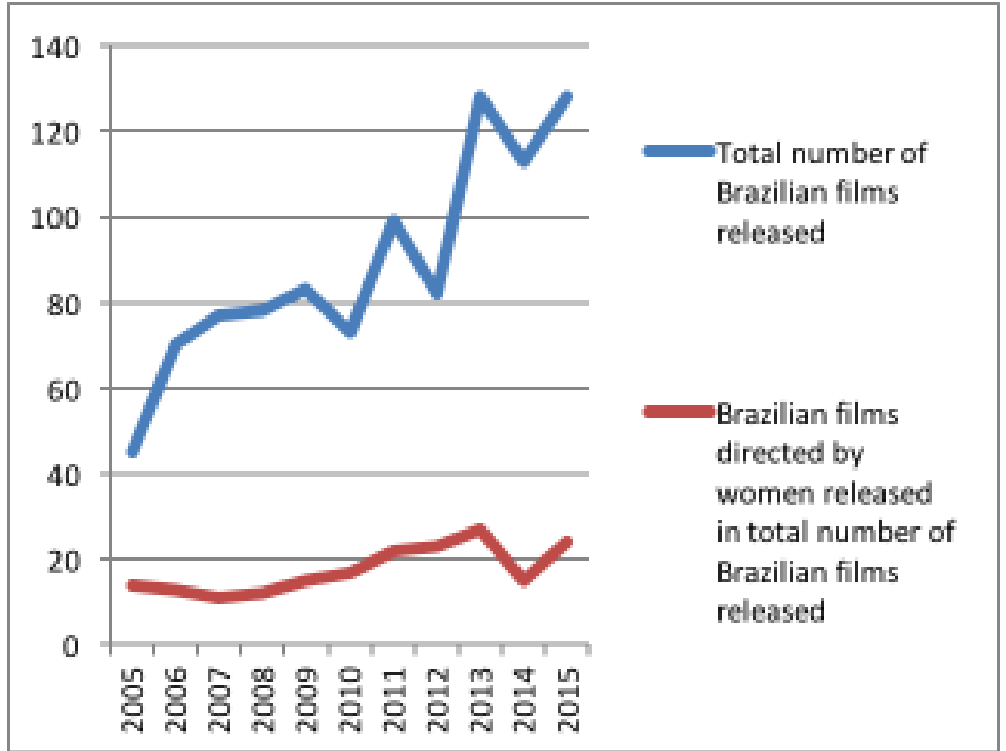

1386 Estudos Feministas, Florianópolis, 25(3): 1373-1389, setembro-dezembro/2017 
It can be noticed that between 2005 and 2015 there was a significant increase in the total number of Brazilian films released, but the number of productions directed by women who managed to debut did not grow in the same proportion. In fact, since 2007 we were in a period where underrepresentation was declining, very slowly and short of women's expectations and needs. However, in 2013 and 2014 we have a new setback, as can be seen in the chart 2, also elaborated by us on the same database.

Graphic 2: percentage of films directed by women within total releases.

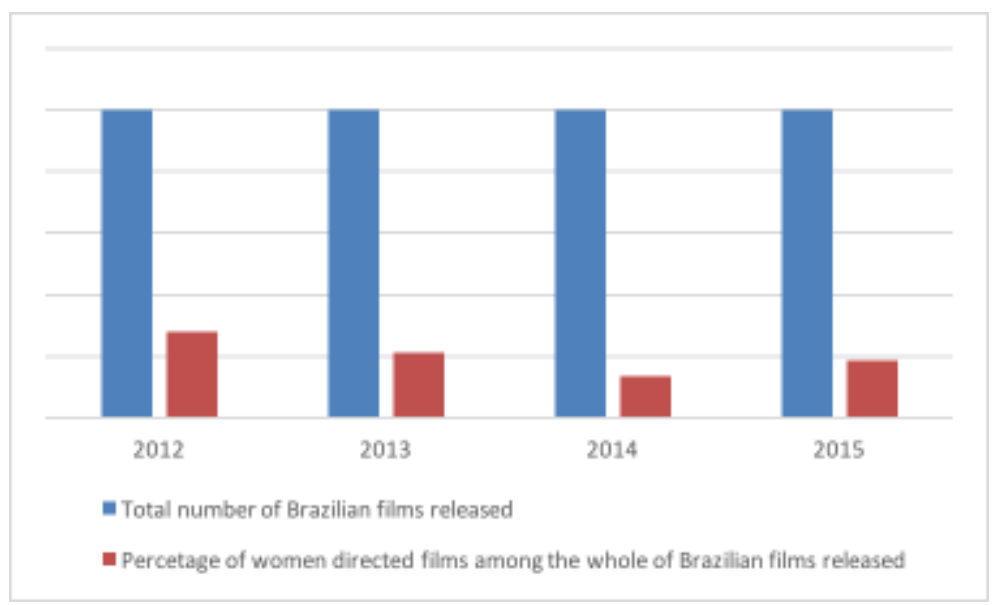

It is curious that in 2015, a year in which some initiatives to promote visibility and equality for women and combat sexism were already underway, as well as the discussions and movements that would result in the appearance of so many others in 2016 , the number of movie releases of women is growing again. When the OCA publishes the 2016 numbers, we will be able to say more properly whether it was a coincidence or not.

The continuity of ANCINE's research on Female presence in Brazilian audiovisual ${ }^{19}$ (2016) will also be of the utmost importance, as it will cover not only the feature films and exhibitions in theatres, but also other areas of production in which it may be easier for women to develop careers as team leaders. In fact, it is important to highlight that this was the first time that ANCINE has devoted so much effort to making a diagnosis of gender inequality, even with the aforementioned limitations, and presented its results in an important place such as Rio Content Market in 2016. Here we believe that it is possible to establish a relationship with this new interest in feminism and its penetration among women in the audiovisual sector.

Finally, taking up what one of the interviewees said, it is still too early to risk drawing hypotheses for the future. And while it is important to celebrate what has been happening, it is necessary to realize that there is still much work to be done. "The woman in the movies is the subject of the moment, but it has to remain a subject. Until it ceases being a subject". ${ }^{20}$

\footnotetext{
${ }^{19}$ Study elaborated by the Supervision of Market Analysis (SAM) / Coordination of the Cinema and Audiovisual Observatory (COB) / Advisory Board of Ancine's Collegiate Board and presented in March 2016 by Débora Ivanov at Rio Content Market. Available at: http://www.ancine.gov.br/sites/default/files/apresentacoes/ Presen\%C3\%A7a\%20Feminina\%20-\%20RCM\%202_0.pdf.

${ }^{20}$ Luísa Pécora, in an interview conducted by email on December 9, 2016.
} 


\section{References}

ANDRADE, Malu. Entrevista sobre o grupo do Facebook Mulheres do Audiovisual. Realizada por e-mail em 8 de dezembro de 2016.

BRASIL, Samantha; VIEIRA, Camila. Entrevista sobre o Cineclube Delas. Realizada presencialmente em 8 de dezembro de 2016.

CANDIDO, Marcos. "Buscas por 'feminismo' e 'empoderamento feminino' cresceram no google - e isso é ótimo”. Elástica, São Paulo, 27/1 1/2015. Disponível em: http://elastica.abril.com. br/buscas-por-feminismo-e-empoderamento-feminino-cresceram-no-google-e-isso-eotimo. Acesso em: 18/12/2016.

CARDOZO, Maria. FINCAR: Diretora artística fala sobre novo festival feminino. Mulher no Cinema, 8/03/2016. Entrevista concedida à Luísa Pécora. Disponível em: http:// mulhernocinema.com/entrevistas/diretora-artistica-fala-sobre-fincar-festival-paramulheres-cineastas/. Acesso em: 18/12/2016.

CINECLUBE DELAS. 100 melhores filmes dirigidos por mulheres no século XXI. Disponível em: https://www.facebook.com/permalink.php?story_fbid $=268076023590486 \& \mathrm{id}=193928527$ 671903\&substory_index $=0$. Acesso em: 18/12/2016.

COGO, Denise; SILVA, Terezinha. "Mídia, alteridade e cidadania da imigração haitiana no Brasil” In: ENCONTRO DA ASSOCIAÇÃO NACIONAL DOS PROGRAMAS DE PÓS-GRADUAÇÃO EM COMUNICAÇÃO, 2015, Brasília. Anais... Brasília: Compós, 2015, p. 1-16.

COSTA, Suely Gomes. 'Onda, rizoma e 'sororidade' como metáforas: representações de mulheres e dos feminismos (Paris, Rio de Janeiro: anos 70/80 do século XX)". Revista Internacional Interdisciplinar INTERthesis, v. 6, n. 2, p. 01-29, jul./dez. 2009.

FERNANDES, Gabriela. Entrevista sobre o coletivo Somos Mais que 30. Realizada por e-mail em 5 de dezembro de 2016.

FESTIVAL INTERNACIONAL DE CINEMA DE REALIZADORAS. Apresentação. Disponível em: http:/ /fincar.com.br/apresentacao/. Acesso em: 18/12/2016.

LINTH, Elen. Entrevista sobre a produtora Eparrêi Filmes. Realizada por e-mail em 10 de dezembro de 2016.

MULHER no cinema. Disponível em: http://mulhernocinema.com/.

MULHERES negras no audiovisual brasileiro. Disponível em: http://mulheresnegrasavbr.com.

OBSERVATÓRIO BRASILEIRO DO CINEMA E DO AUDIOVISUAL. Informe de Acompanhamento do Mercado. Produção de Longas-Metragens. Disponível em: http://oca.ancine.gov.br/sites/ default/files/cinema/pdf/informe_producao_2014.pdf. Acesso em: 18/12/2016.

Filmes Brasileiros Lançados - 1995 a 2015 . Disponível em: http://oca.ancine.gov.br/ sites/default/files/cinema/pdf/2102_1.pdf. Acesso em: 18/12/2016.

OLIVEIRA JÚNIOR, Luiz Carlos Gonçalves de. Vertigo, a teoria artística de Alfred Hitchcocke seus desdobramentos no cinema moderno. 2015. Tese (Doutorado em Meios e Processos Audiovisuais), Programa de Pós-Graduação em Meios e Processos Audiovisuais, Escola de Comunicação e Artes da USP, São Paulo.

RODRIGUES, Carol. Entrevista sobre Mulheres Negras no Audiovisual Brasileiro Carol. Realizada por e-mail em 12 de dezembro de 2016.

SARMET, Érica; TEDESCO, Marina Cavalcanti. "Cineclubismo e mulheres cineastas no estado do Rio de Janeiro: a experiência do cineclube Quase Catálogo". Revista Moventes, v. 1, n. 1 , set. 2016.

TÉLÉRAMA. Les 100 meilleurs films de l'histoire selon "Télérama". Disponível em: http:// www.telerama.fr/cinema/les-100-meilleurs-films-de-l-histoire-selon-telerama, 149864.php. Acesso em: 9/12/2016. 
TOSTE, Verônica; CANDIDO, Marcia Rangel. O Brasil das telas de cinema é um país branco. Disponível em: http://gemaa.iesp.uerj.br/publicacoes/infografico/infograficol.html. Acesso em: 18/12/2016.

\section{Films}

ACADEMIA das musas. Direção: José Luis Guerín. Espanha, 2015.

BAHÊA minha vida. Direção: Márcio Cavalcante. Gênero: Documentário, Brasil, 2011.

ELA fica linda quando está com raiva. Direção: Mary Dove. Gênero: Documentário, 2014.

ELENA. Direção: Petra Costa. Roteiro: Carolina Ziskind, Petra Costa. Produção: Julia Bock. Gênero: Biografia/Documentário, Brasil, 2012, 82min.

CÁSSIA Eller. Direção e roteiro: Paulo Henrique Fontenelle. Produção: lafra Britz. Brasil, 2014, $120 \mathrm{~min}$.

CORPO que cai, Um. Direção: Alfred Hitchcock. Produtores: Alfred Hitchcock, Herbet Coleman. Gênero: Mistério/Romance/Thriller, EUA, 1958, 128min.

GAROTAS. Direção: Céline Sciamma. Gênero: Drama, França, 2015, 112min.

GUERRA ao terror. Direção: Kathryn Bigelow. Roteiro: Mark Boal. Produtores: Donall McCusker, Greg Shapiro, Jack Schuster, Jenn Lee, Kathryn Bigelow, Mark Boal, Nicolas Chartier, Tony Mark. Gênero: Ação/Drama/Guerra, EUA, 2008, 128min.

O INíCIO, o fim e o meio - Raul. Direção: Walter Carvalho, Leonardo Gudel, Evaldo Mocarzel. Roteiro: Leonardo Gudel. Produtores: Alain Fresnot, Denis Feijão. Gênero: Biogarfia/ Documentário, Brasil, 2012, 128min.

RESPOSTA das mulheres. Direção: Agnés Varda. Gênero: Documentário, França, 1975.

TARJA branca. Direção: Cacau Rhoden. Roteiro: Marcelo Negri. Produção: Juliana Borges. Gênero: Documentário, Brasil, 2014, 80min.

[Recebido em 13/02/2017

e aprovado em 30/03/2017]

Érica Sarmet (e.sarmet@gmail.com) é pesquisadora em Comunicação e Cultura e roteirista. Mestre em Comunicação pelo Programa de Pós-Graduação em Comunicação da Universidade Federal Fluminense (UFF), é bacharel em Estudos de Mídia pela mesma instituição. Integra, desde 2009, o NEX - Núcleo de Estudos do Excesso nas Narrativas Visuais, vinculado ao PPGCOM/UFF. É também fundadora do Cineclube "Quase Catálogo", dedicado a filmes dirigidos por mulheres. Atua nas áreas de Comunicação e Cultura, com ênfase nos seguintes temas: cinema e audiovisual, estudos culturais, pornografia, gênero e sexualidade, roteiro audiovisual.

Marina Cavalcanti Tedesco (ninafabico@gmail.com) atua nas áreas de Roteiro, Direção e, principalmente, Direção de fotografia. É doutora em Comunicação e professora do Departamento de Cinema e Vídeo da Universidade Federal Fluminense e do Programa de Pós-Graduação em Estudos Contemporâneos das Artes na mesma instituição. Entre suas publicações de maior relevância, destacam-se a coorganização das coletâneas BrasilMéxico: aproximações cinematográficas (2013) e Corpos em Projeção: gênero e sexualidade no cinema latino-americano. É uma das organizadoras do Cineclube "Quase Catálogo". 